\title{
IMPACT OF CREATIVITY ON STUDENT ENTREPRENEURIAL INTENTION
}

\author{
IMPACTO DA CRIATIVIDADE NA INTENÇÃO EMPREENDEDORA DO ALUNO
}

IMPACTO DE LA CREATIVIDAD EN LA INTENCIÓN EMPRENDEDORA DE LOS ESTUDIANTES

\author{
Thuy Thu Nguyen ${ }^{1}$ \\ Hoa Thi Thanh Phan ${ }^{2}$ \\ iD Van Thanh Pham $^{3}$
}

\section{Cite as - American Psychological Association (APA)}

Nguyen, T. T., Phan, H. T. T., \& Pham, V. T. (2021, Sept./Dec.). Impact of creativity on student entrepreneurial intention. International Journal of Innovation - IJI, São Paulo, 9(3), 646-663.

https://doi.org/10.5585/iji.v9i3.19659.

\begin{abstract}
Objective of the study: This empirical research tests the direct and indirect impact of creativity on entrepreneurial intention, by applying the theory of planned behavior (TPB) as the underpinning framework.
\end{abstract}

Methodology/approach: Quantitative research was conducted through a survey of 703 undergraduate students in Vietnam. Structural equation modeling with Amos version 23 was used to test the theoretical model.

Originality/Relevance: Creativity is assumed to be a common characteristic of entrepreneurs and a prerequisite for innovation and entrepreneurship, but the findings on the influence of creativity on entrepreneurship intention are inconsistent in literature. This research uses a mediator effect to explain this inconsistency and focuses on the direct and indirect impact of creativity on entrepreneurship intention in an Asian emerging country.

Main results: Analytical results show that creativity has no significant direct effect on entrepreneurial intention. Rather, it has an indirect effect on entrepreneurial intention through three determinants (attitude, subjective norms, and behavioral control).

Theoretical/methodological contributions: The study provides empirical evidence to confirm the importance of attitude, subjective norms, and behavioral control, which together fully mediate the impact of creativity on entrepreneurial intention.

\footnotetext{
${ }^{1} \mathrm{PhD}$ in Business management Faculty. National Economics University. Hanoi - Vietnam. thuyntqtkd@ neu.edu.vn

2 PhD in Business management Faculty. National Economics University. Hanoi - Vietnam. hoaptt@ neu.edu.vn

3 PhD candidate in Business management Faculty. National Economics University. Hanoi - Vietnam. ptvan@neu.edu.vn
} 
Social/management contributions: These results have several implications for promoting entrepreneurship in university students.

Keywords: Entrepreneurial intention. Creativity. Theory of planned behavior model.

\section{Resumo}

Objetivo do estudo: Esta investigação empírica tem como objetivo testar o impacto direto e indireto da criatividade nas intenções empresariais, aplicando a teoria do comportamento planeado (TPB) como um quadro subjacente.

Metodologia/abordagem: Um estudo quantitativo é conduzido através de uma pesquisa que inclui 703 estudantes de graduação no Vietname. Análise do modelo de equação trónica (SEM) com AMOS 23 foi usada para testar o modelo teórico.

Originalidade/Relevância: A criatividade assume-se como uma característica comum dos empreendedores, um pré-requisito necessário para a inovação e o empreendedorismo, mas a influência da criatividade na intenção de empreendedorismo é inconsistente na literatura. Esta pesquisa utiliza o efeito mediador para explicar esta relação de inconstância. Assim, este estudo centra-se no impacto direto e indireto da criatividade na intenção de empreendedorismo num país emergente asiático

Principais resultados: Resultados analíticos mostram que a criatividade não tem um efeito direto significativo na intenção empresarial. Em vez disso, tem um efeito indireto na intenção empresarial através de três determinantes da intenção empresarial (atitude, normas subjetivas e controlo comportamental).

Contribuições Teóricas/metodológicas: $\mathrm{O}$ estudo fornece provas empíricas para confirmar a importância da atitude, das normas subjetivas e do controlo comportamental que mediam plenamente o impacto da criatividade na intenção empresarial.

Contribuições sociais/de gestão: Estes resultados sugerem várias implicações para promover o empreendedorismo nos estudantes universitários.

Palavras-chave: Intenção empreendedora. Criatividade. Modelo de teoria do comportamento planejado.

\section{Resumen}

Objetivo del estudio: Esta investigación empírica pretende probar el impacto directo e indirecto de la creatividad en las intenciones empresariales aplicando la teoría del comportamiento planificado (TCP) como marco de apoyo.

Metodología/Enfoque: Se realiza una investigación cuantitativa a través de una encuesta que incluye a 703 estudiantes de grado en Vietnam. Se utilizó el análisis del modelo de ecuación estructural (MEE) con AMOS 23 para probar el modelo teórico.

Originalidad/Relevancia: Se asume que la creatividad es una característica común de los emprendedores, un requisito previo necesario para la innovación y el emprendimiento, pero la influencia de la creatividad en la intención de emprendimiento es inconsistente en la literatura. Esta investigación utiliza el efecto mediador para explicar esta relación de inconstancia. Así, este estudio se centra en el impacto directo e indirecto de la creatividad en la intención emprendedora en un país emergente asiático. Resultados principales: Los resultados analíticos identifican que la creatividad no tiene un efecto directo significativo en la intención empresarial. En cambio, tiene un efecto indirecto sobre la intención empresarial a través de tres determinantes de la intención empresarial (actitud, normas subjetivas y control de comportamiento).

Contribuciones teóricas/metodológicas: El estudio proporciona evidencia empírica para confirmar la importancia de la actitud, las normas subjetivas y el control conductual que median plenamente el impacto de la creatividad en la intención emprendedora.

Contribuciones sociales/gerencias: Estos resultados sugieren varias implicaciones para promover el emprendimiento en estudiantes universitarios.

Palabras clave: Intención emprendedora. Creatividad. Teoría del modelo de comportamiento planificado. 


\section{Introduction}

A high rate of new firm formation contributes greatly to national economic development, job creation, and social wealth (Pereira et al. 2018). Understanding the factors that significantly promote new venture creation is key to economic development (Bruton, Ahlstrom \& Obloj, 2008). As a planned, conscious, complex, and risky behavior, many factors influence the entrepreneurship decision-making process, and entrepreneurial intention is a crucial factor driving entrepreneurial action and behavior (Bird, 1988). Thus, many scholars, governments, and educational institutions have taken initiatives to try to understand and unlock the factors that drive the entrepreneurial intention of students. Scholars have highlighted the dynamic interaction between the cognitive properties that trigger individuals to identify and exploit opportunities and entrepreneurial intention (Krueger, Reilly \& Carsrud, 2000). Among cognitive perspectives properties, a growing stream of research has recognized creativity as a key component of entrepreneurship, since entrepreneurs have to identify opportunities, generate new ideas, and be innovative (Fillis and Rentschler, 2010; Pereira, et al., 2018). Hamidi, Wennberg and Berglund (2008) suggested that creativity is one of the main factors promoting new firm creation and innovation and, in turn, economic growth. Smith, Sardeshmukh and Combs (2016) reveal that individuals who are more creative are more likely to take the initiative in entrepreneurship. Creative individuals form innovative start-ups and influence the type and level of novelty in ideas that they launch. Creativity is an essential part of entrepreneurship and has been identified as influencing entrepreneurial intention (Ward, 2004).

Despite growing consensus and awareness of the important role of creativity as a source of knowledge and innovation in entrepreneurship, researchers suggest that there is a need for further empirical research on creativity, in particular, to identify the connections between creativity and entrepreneurship in the context of universities (Bruton et al., 2008; Schmitz, Urbano, Dandolini, Souza, \& Guerrero, 2017). The field of research on creativity and entrepreneurial intention needs to be extended by linking it with different mechanisms (Rui, $\mathrm{Li}$, Wei, \& Peng, 2018). In addition, although a number of studies (such as those of Biraglia and Kadile (2016), Minano and Campo (2017) and Smith et al. (2016) have attempted to explore the direct impact of individual creativity on entrepreneurial intention, their findings are inconsistent (Shahab, Chengang, Arbizu, \& Haider, 2018). This inconsistency in previous research highlights the need to improve our understanding of the relationship between creativity and entrepreneurial intention. Mario, Antonia, and Domingo (2018), Tsai, Chang and Peng (2016) and Shahab et al. (2018) proposed extending the literature on the determinants of 
entrepreneurial intention by examining mediating and moderating effects and studying other entrepreneurship-related variables to reveal interesting findings.

This study applies the theory of planned behavior (TPB) to explore the link between creativity and entrepreneurial intention. TPB was chosen as the theoretical framework for our study because of its strengths shown in previous research in this field (Krueger et al., 2000; Tsai et al., 2017)

This research further extends the literature on entrepreneurship in two ways. First, in this study, we provide insights into the role of individual creativity in the context of universities in a developing country with a collectivist culture, where social pressure can affect individual attitudes toward certain behaviors. Second, this study enables a deeper understanding of the relationship between creativity and entrepreneurship intention by investigating mediation effects using the TPB model. This paper employs confirmatory factor analysis (CFA) and structural equation modeling (SEM) to examine the mediating relationship.

This article starts with a literature review on creativity and entrepreneurship intention, then sets out methodological considerations for the empirical study and presents the findings and a discussion of the results. The final section contains the conclusions, limitations, and suggestions for future research.

\section{Literature review}

\subsection{Entrepreneurial intention and the theory of planned behavior}

Entrepreneurial intention is defined as mental orientation (desire, wish, and hope) inducing the selection of self-employment (Krueger et al., 2000). Since entrepreneurial behavior is a type of planned behavior and entrepreneurial intention is therefore the single strongest predictor and explanation for entrepreneurial behavior, entrepreneurial intention is crucial to understanding the entrepreneurship process. The first step in exploring the complex process of entrepreneurship is to study entrepreneurial intention and its antecedents (Krueger et al., 2000).

Various models have been developed to identify the factors affecting the intention to engage in an entrepreneurial career. Based on the theory of rational action, Ajzen (1991) proposed TPB, which recognizes three cognition variables that explain the variance in entrepreneurial intention: attitude toward the behavior, perceived behavioral control, and subjective norms. Perceived subjective norms are the individual's perception of the opinion of other people (who are considered important to the individual) in respect of a certain behavior 
(Krueger et al., 2000). Liñán and Chen (2009) described perceived behavioral control as not only the feeling of having the necessary skills to start a new venture and succeed with it but also the perception of being in control. Attitude refers to the evaluation of entrepreneurship (favorable or unfavorable) made by the person (Ajzen, 1991). The TPB model has been widely applied in entrepreneurship research, and numerous empirical studies have confirmed that model can explain entrepreneurial intention. Studies in the entrepreneurship literature based on TPB report that perceived behavioral control, subjective norm, and attitude toward the behavior typically explain 30-45\% of the variance in entrepreneurial intention (Miranda, Mera, \& Rubio, 2017; Linan \& Chen, 2009; Krueger et al., 2000).

\section{Hypothesis 1: Entrepreneurial attitude positively impacts entrepreneurial intention.}

Hypothesis 2: Perceived behavior control positively impacts entrepreneurial intention. Hypothesis 3: Subjective norms positively impacts entrepreneurial intention.

\subsection{Subjective norms and entrepreneurial attitude}

Subjective norms are the views of other people with influence, who are considered important by the individual and who can advise them to perform or not perform certain behaviors; these views influence the motivation and willingness of an individual to become an entrepreneur (Ajzen, 1991). Subjective norms are part of the social culture of entrepreneurship and imply that there is social pressure on individuals to perform or not perform a certain behavior, providing motivation to respond to this pressure (Miranda et al., 2017).

Vietnam is a high collectivist culture (Duong, 2019), meaning that its social fabric emphasizes the importance of cohesive groups (family, clan, company) in building individual cognition. In this culture, collective goals may outweigh individual predispositions (Hofstede, 2001). Motivation to comply with the norms of the "in-group" may be particularly strong in this cultural context, and positive norms in respect of entrepreneurship could be expected to encourage individuals to start new ventures (Nguyen, Dinh, Luu and Choo 2020). Further, Bruton et al. (2008) and Yousaf, Shamim, Siddiqui, and Raina (2015) found that in emerging countries, students receive less support from the government and institutional network to establish their own businesses, and so depend to a greater extent on support from family, friends, colleagues, and relatives. Thus, the views of these people are decisive in shaping individual perception and cognition, and so we propose that culture may influence the entrepreneurial mindset through social legitimation in promoting positive attitudes. 


\section{Hypothesis 4: Subjective norms positively impact entrepreneurial attitude.}

\subsection{Creativity and entrepreneurial intention}

There are various definitions of creativity in the literature, as it is quite an ambiguous concept (Ward, 2004). Creativity involves the production of novel and useful products and ideas in any domain, or the formulation or creation of something that was not previously available in its present state (Zampetakis \& Moustakis, 2006). Fillis and Rentschler (2010) contended that a creative individual solves problems, fashions products, or poses new questions within a domain, in a way that is initially considered to be unusual but is eventually accepted within at least one cultural group. We followed a trend initiated by Hinton (1968) and taken up by Laguíaa, Morianoa, and Gorgievskib (2019) to consider creativity as a critical skill that a successful entrepreneur must have. Creativity at an individual level consists of a belief in or perceptions of an individual's own ability to be creative. Creativity refers to the individual's self-efficacy in which entrepreneurs can start innovative businesses by combining existing resources and generating new ideas (Laguíaa et al., 2019).

Opportunity recognition is the first step in the entrepreneurial process and is often seen as crucial to it (Biraglia \& Kadile, 2016). Creativity is a key success factor in entrepreneurship as it helps to recognize the association between problems and solutions, identify innovative ideas to respond to an opportunity, and shape or reform available resources in a novel way (Hamidi et al., 2008). Creativity helps entrepreneurs in an individual cognitive process by combining and matching knowledge and information (Miranda et al., 2017). With the emergence of studies of entrepreneurship intention, many researchers have identified creativity as essential in promoting entrepreneurship intention because entrepreneurship itself is a creative activity. Novelty and effectiveness are the hallmarks of creative ideas, and students' creative disposition impacts their desire to engage in entrepreneurship. Individuals with a strong belief in their creativity are the most highly motivated to become self-employed (Zampetakis \& Moustakis, 2006). Rui et al. (2018) argued that creative thinking can also impact the means of coping with the frustrating situations that an individual may face. Therefore, creative thinking can be considered as one of the key, yet little-studied, antecedents of entrepreneurial intention and action (Zampetakis \& Moustakis 2006; Ward, 2004). Although empirical research by Minano and Campo (2017) and Miranda et al. (2017) failed to support the hypothesis that individuals with an anchor in creativity are more inclined to form a new business, studies by 
Biraglia and Kadile (2016) and Zampetakis and Moustakis (2006) reported a strong positive association between self-perceived creativity and entrepreneurial intention.

\section{Hypothesis 5: Individual creativity positively impacts entrepreneurial intention.}

\subsection{Mediating effects}

In the TPB model (Ajzen, 1991), attitudes to behavior, subjective norms, and perceived behavioral control are substantive determinants of intention, while other exogenous factors indirectly impact entrepreneurial intention through these components. Miranda et al. (2017) showed that there is no direct relationship between creativity and entrepreneurial intention; rather, an indirect relationship exists through mediators. Therefore, we propose that creativity indirectly relates to entrepreneurial intention through perceived behavioral control, attitudes to entrepreneurship, and subjective norms.

First, individuals' belief in their ability to act creatively is a key component of a successful creative performance (Biraglia and Kadile, 2016). A high level of creativity supports a strong belief that a new venture can be initiated successfully and thus gives rise to a positive perception of behavioral control in respect of the creation of the new venture. Previous studies by Biraglia and Kadile (2016), Shahab et al. (2018), and Mario et al. (2018) showed that the effect of creativity on entrepreneurial intention is fully mediated by self-efficacy. Self-efficacy and perceived behavioral control are different but overlapping concepts (Krueger et al., 2000). We therefore propose that:

Hypothesis 6: Creativity positively impacts perceived behavioral control and, through perceived behavioral control, indirectly impacts entrepreneurial intention.

Second, since attitudes to entrepreneurship on the part of individuals include expectations that an entrepreneurial career would provide opportunities to express their creative ability, entrepreneurship allows individuals to take advantage of their creativeness (Ward, 2004) and put it to good use (Schmidt et al., 2012). Creative students can be expected to value entrepreneurship more than do students who perceive themselves as being less creative (Miranda et al., 2017). Creativity is expected to be linked with positive attitudes to entrepreneurship. A high degree of confidence in an individual's creative ability gives rise to a belief that favors the initiation of a new venture over other career choices. This belief ultimately 
encourages and motivates a positive attitude to entrepreneurship. Miranda et al. (2017) and Schmitz (2017) revealed that academics who perceive they have the ability to be creative are more willing to express their engagement in entrepreneurial activities. Therefore, we posit that:

Hypothesis 7: Creativity positively impacts attitudes to entrepreneurship and, through I,t indirectly impacts entrepreneurial intention.

Third, it is a widely accepted assumption that an entrepreneur is a person who creates something new and uses creative means to exploit a market opportunity; thus, creativity is an important trait among entrepreneurs (Ward, 2004), who can be thought of as creative people (Zampetakis \& Moustakis, 2006). Further, individuals will likely believe that other people who are important to them (parents, friends, and colleagues) also expect that a creative person should engage in a career in entrepreneurship (Laguíaa et al. 2019). Students' perceptions of creativity can interact with these perceptions to form a normative belief (Fillis and Rentschler, 2010). Students who perceive themselves as creative may think that other people expect them to become entrepreneurs. In cases where students perceive themselves to be less creative, they may feel the need to avoid high expectations and perceive a negative subjective norm in society.

Hypothesis 5c. Creativity positively impacts subjective norms and, through subjective norms, indirectly impacts entrepreneurial intention.

The literature has linked gender and business experience with entrepreneurial intention (Biraglia and Kadile, 2016; Miranda et al., 2017; Smith et al, 2017). Therefore, we included gender and business experience as control variables in the theoretical model to improve the validity of the findings and reduce the confounding effect of variations.

\section{Methodology}

To test our assumptions, we used an empirical approach that measured the impact of creativity on entrepreneurial intention, based on the framework of the TPB model.

All measurements were adopted from previous studies. Measurements were translated to Vietnamese, then back to English to ensure the accuracy of words and meanings. Then, qualitative pre-testing of the questionnaire was carried out by inviting ten non-participating students and three professors to review all the questions. All scales were measured on a five- 
point Likert scale ranging from 1 ('strongly disagree') to 5 ('strongly agree'). The respondents were asked to assess their level of agreement with each statement.

Entrepreneurial intention (DD). The scale was adapted from Liñán and Chen (2009) and includes six items, such as 'I intend to start my own business in the near future'. The Cronbach's alphafor this scale was 0.889 .

Subjective norms $(C Q)$. The construct was measured by a three-item scale adapted from Liñán and Chen (2009). The Cronbach's alpha for this scale was 0.838 .

Entrepreneurial attitude (TD). We measured this construct using a five-item scale from Liñán and Chen (2009). The Cronbach's alpha for this scale was 0.822.

Perceived behavior control $(H V)$. We used a six-item scale from Liñán and Chen (2009). The Cronbach's alpha for this scale was 0.874 .

Individual creativity (ST). We provided a definition of creativity at the beginning of the questionnaire to ensure that all our respondents had a common understanding. We used a selfreporting method when measuring individual creativity, given that a creative individual has a firm sense of self as a creative person. Consistent with the earlier research of Biraglia and Kadile (2016), we used a six-item scale such as "I often come up with creative solutions to problems," "I often have new and innovative ideas," and "I often promote and champion ideas to others." The Cronbach's alpha for this scale was 0.889 .

The survey was conducted in Hanoi, the capital of Vietnam, where most of the large universities in the North of Vietnam are located. A convenience sampling technique was used. Final year undergraduate students volunteered to take part in the survey; these students are of particular interest as they are young adults who are about to choose their careers. Samples of undergraduate students are often used in entrepreneurship research (Minano \& Campo, 2017; Schmidt et al., 2012). Questionnaires were self-completed by the students. Data collection was conducted in two ways. First, soft electronic copies of the survey questionnaire were sent online via Google Docs. Students were asked and reminded to answer the questionnaire by email. 247 students answered the questionnaire (response rate 27\%). Second, hard copies of survey 
questionnaires were sent directly to students, and 456 responses were collected. We controlled the representativeness of the sample during the survey, by major and university. The final sample comprised 703 respondents from 30 universities. Of the undergraduate students surveyed, all were senior students, and $64.9 \%$ were male and $35.1 \%$ female. In terms of majors, $49 \%$ were business and economic management, $38 \%$ were science and engineering, and $13 \%$ were other majors. In terms of family experience, $28.3 \%$ of respondents had family involvement in entrepreneurial activities, and $71.7 \%$ had no experience of entrepreneurial activities.

\section{Results and discussion}

\subsection{Results}

As we use self-reported data, to minimize the potential for common method bias, we informed survey participants that their responses would be kept confidential and used only for scientific research (Podsakoff et al., 2003). The questionnaires were answered anonymously. Then, we applied Harman's one factor to test for common method bias. All the items (measuring latent variables) were loaded into one common factor with unrotated principal component factor analysis. The result showed that the total variance explained by a single factor is only $18.75 \%$, which is well below the critical value of $40 \%$. The result thus confirms the absence of any serious common method bias in the study.

SPSS 23.0 was used to test the reliability and validity of the measurements. Cronbach's alpha and the first exploratory factor analysis (EFA) showed that three items needed to be excluded from further analysis; they loaded in other constructs differently from the original scale and Cronbach's alpha was not qualified. The items HV5, DD1 and TD5 related to measurements of behavior control, intention and attitude, respectively, were eliminated one by one from the original scales. Last, Cronbach's alpha and EFA were conducted again (Table 1). Cronbach's alpha for each construct was between 0.822 and 0.889 , and the values of the average variance extracted (AVE) were greater than 0.5 , which is considered to be good reliability (Hair, Black, Babin, \& Anderson, 2010).

EFA gave a Kaiser Meyer Olkin (KMO) test result of 0.927, with a significant Bartlett's test $(\mathrm{v} 2=9027.942, \mathrm{p}<0.001)$ and $68.771 \%$ of the total variance explained. All the reflective construct loadings exceeded the 0.6 reference value, and no item had higher loadings in constructs different from the original scale. The scales are considered to be of good validity (Hair et al., 2010). 


\section{Table 1}

Cronbach's alpha and EFA analysis

\begin{tabular}{|c|c|c|c|c|c|c|c|}
\hline \multirow{2}{*}{ Constructs } & & \multicolumn{5}{|c|}{ Component } & \multirow{2}{*}{ Cronbach alpha } \\
\hline & & 1 & 2 & 3 & 4 & 5 & \\
\hline \multirow{6}{*}{ Creativity (ST) } & ST4 & .816 & & & & & \multirow[t]{6}{*}{0.889} \\
\hline & ST6 & .803 & & & & & \\
\hline & ST1 & .798 & & & & & \\
\hline & ST5 & .797 & & & & & \\
\hline & ST2 & .791 & & & & & \\
\hline & ST3 & .791 & & & & & \\
\hline \multirow{5}{*}{$\begin{array}{l}\text { Perceived behaviour control } \\
\text { (HV) }\end{array}$} & HV4 & & .854 & & & & \multirow[t]{5}{*}{0.874} \\
\hline & HV6 & & .804 & & & & \\
\hline & HV1 & & .777 & & & & \\
\hline & HV3 & & .757 & & & & \\
\hline & HV2 & & .736 & & & & \\
\hline \multirow{5}{*}{$\begin{array}{l}\text { Entrepreneurial intention } \\
\text { (DD) }\end{array}$} & DD4 & & & 95 & & & \multirow[t]{5}{*}{0.889} \\
\hline & DD5 & & & 74 & & & \\
\hline & DD2 & & & 84 & & & \\
\hline & DD6 & & & 82 & & & \\
\hline & DD3 & & & 41 & & & \\
\hline \multirow{4}{*}{$\begin{array}{l}\text { Entrepreneurial attitude } \\
\text { (TD) }\end{array}$} & TD1 & & & & 38 & & \multirow{4}{*}{0.822} \\
\hline & TD4 & & & & 751 & & \\
\hline & TD3 & & & & 10 & & \\
\hline & TD2 & & & & 660 & & \\
\hline \multirow{3}{*}{$\begin{array}{l}\text { Subjective norms } \\
\text { (CQ) }\end{array}$} & CQ2 & & & & & 389 & \multirow[t]{3}{*}{0.838} \\
\hline & CQ3 & & & & & 362 & \\
\hline & CQ1 & & & & & 834 & \\
\hline
\end{tabular}

Notes: Extraction Method: Principal Component Analysis.

Rotation Method: Promax with Kaiser Normalization.

Rotation converged in 6 iterations.

Source: Our own study.

Confirmatory factor analysis was used to find the relationship between items and latent variables. In the measurement model, an adequate model fit was found, with the following indices: $\chi 2=661.619, \chi^{2} / \mathrm{df}=2.584, \mathrm{TLI}=.947, \mathrm{GFI}=.930, \mathrm{IFI}=0.959, \mathrm{CFI}=0.955, \mathrm{AGFI}$ $=0.911, \mathrm{RMR}=0.047, \mathrm{RMSEA}=0.048$. The construct reliability was assessed using composite reliability (CR) above 0.7 and was considered to be adequate. AVE values were well above the cut-off of 0.5 , and discriminant validity MSV $<$ AVE ensured the convergent validity of all the scales (Hu and Bentler, 1999) (Table 2). 
Table 2

Measurement's reliability

\begin{tabular}{|l|l|l|l|l|l|l|l|l|l|}
\hline & CR & AVE & MSV & $\operatorname{MaxR}(\mathbf{H})$ & ST & HV & DD & TD & CQ \\
\hline ST & 0.889 & 0.571 & 0.254 & 0.889 & $\mathbf{0 . 7 5 6}$ & & & & \\
\hline HV & 0.870 & 0.573 & 0.392 & 0.873 & $0.476^{* * *}$ & $\mathbf{0 . 7 5 7}$ & & & \\
\hline DD & 0.891 & 0.622 & 0.450 & 0.898 & $0.504^{* * *}$ & $0.626^{* * *}$ & $\mathbf{0 . 7 8 9}$ & & \\
\hline TD & 0.824 & 0.544 & 0.450 & 0.844 & $0.406^{* * *}$ & $0.272^{* * *}$ & $0.671^{* * *}$ & $\mathbf{0 . 7 3 7}$ & \\
\hline CQ & 0.842 & 0.641 & 0.354 & 0.848 & $0.393^{* * *}$ & $0.335^{* * *}$ & $0.549^{* * *}$ & $0.595^{* * *}$ & $\mathbf{0 . 8 0 0}$ \\
\hline
\end{tabular}

Source: Our own study.

To test our hypotheses, we applied SEM with a bootstrapping method following Preacher and Hayes (2004) to assess the mediation effect.

Hypothesis 1: The standardized regression weight of entrepreneurial attitude on entrepreneurial intention was 0.488 ; sig. $<0.001$. Hypothesis 2: The standardized regression weight of subjective norms on entrepreneurial intention was significant at 0.134 ; sig $<0.005$. Hypothesis 3: The standardized regression weight of perceived behavioral control on entrepreneurial intention was significant at 0.415 ; sig. $<0.001$. Hypothesis 4 : The standardized regression weight of subjective norms on entrepreneurial attitude was significant at 0.510 ; sig $<0.001$. Therefore, we can conclude that hypotheses $\mathrm{H} 1, \mathrm{H} 2, \mathrm{H} 3, \mathrm{H} 4$ are supported by the research results.

Table 3

SEM with bootstrapping method (5000 replications)

\begin{tabular}{lcl|clll}
\hline \multicolumn{2}{c}{ Hypothesis } & Estimate & \multicolumn{1}{c}{ S.E. } & C.R. & P \\
\hline CQ & $<--$ & ST & .482 & .054 & 8.902 & $* * *$ \\
CQ & $<---$ & BE & .056 & .069 & .816 & .415 \\
CQ & $<--$ & Sex & -.122 & .064 & -1.920 & .055 \\
HV & $<---$ & ST & .542 & .054 & 10.009 & $* * *$ \\
TD & $<--$ & ST & .160 & .038 & 4.155 & $* * *$ \\
TD & $<---$ & CQ & .370 & .038 & 9.623 & $* * *$ \\
TD & $<---$ & sex & .015 & .042 & .346 & .729 \\
TD & $<---$ & BE & .097 & .045 & 2.136 & .033 \\
HV & $<---$ & Sex & .110 & .062 & 1.789 & .074 \\
HV & $<--$ & BE & .165 & .067 & 2.468 & .014 \\
DD & $<---$ & HV & .433 & .040 & 10.821 & $* * *$ \\
DD & $<--$ & TD & .709 & .075 & 9.429 & $* * *$ \\
DD & $<---$ & CQ & .141 & .043 & 3.257 & .001 \\
DD & $<--$ & ST & .068 & .049 & 1.387 & .166 \\
DD & $<---$ & Sex & .102 & .048 & 2.121 & .034 \\
DD & $<---$ & BE & .091 & .052 & 1.732 & .083 \\
\hline
\end{tabular}

Notes: Creativity (ST), Perceived behaviour control (HV), Entrepreneurial intention (DD), Entrepreneurial attitude (TD), Subjective norms (CQ), BE (business experiences).

Source: Our own study. 


\section{Figure 1}

\section{SEM analysis}

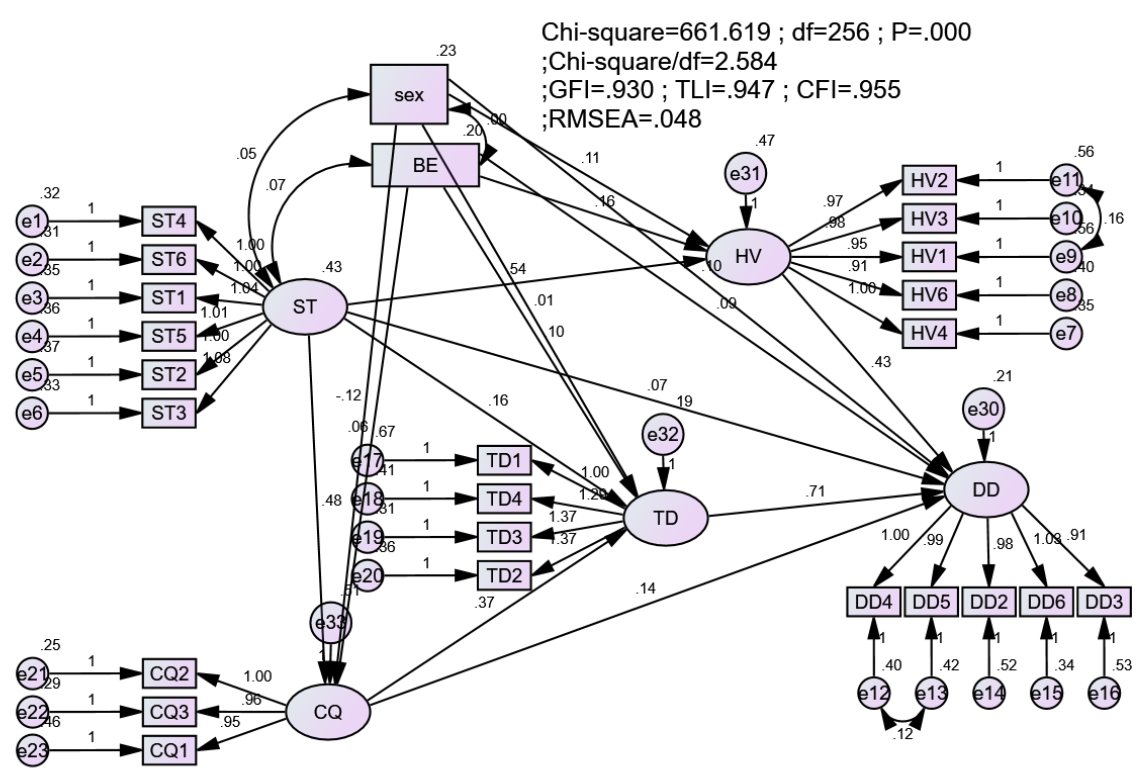

Source: Our own study.

The impact of creativity on entrepreneurial intention was not significant (sig. $=0.166>$ 0.05). Hypothesis 5 is not supported by the research data. Interestingly, creativity significantly relates to perceived behavioral control, entrepreneurial attitude, and subjective norms (standardized regression weight $=.487 * * * ; .186 * * * ; .407 * * *$ respectively; level of confidence 95 percent, number of bootstrapping resamples 5,000, two-tailed significance of total, indirect and direct effect <0.001). Thus, perceived behavioral control, entrepreneurial attitude, and subjective norms fully mediate the impact of creativity on entrepreneurial intention. Thus, hypotheses H6, H7, H8 are supported by the research data. Table 3 shows the relationship between creativity, three exogenous factors (attitude toward entrepreneurship, subjective norms, and behavioral control) and entrepreneurial intention in the TBP model. Figure 1 shows the SEM results with an adequate model fit index.

\subsection{Discussion}

In line with the empirical evidence of current research on the mechanism of how people pursue their entrepreneurial careers (Krueger et al., 2000; Linan \& Chen, 2009; Yousaf et al., 2015, Nguyen, 2020), the results support the TPB model. This study posits that forming new business ventures is a challenging task that requires confidence in an individual's own ability 
as well as social encouragement. Individuals' entrepreneurial intention is a result of an interaction between attitude, and behavioural control elements, suggesting reciprocal interrelatedness. Previous research has shown that the relationship between subjective norms and entrepreneurial intention is not significant (Krueger et al., 2000; Miranda, et al., 2017). However, in this study, in a Vietnam collectivist culture, this relationship is significant. Families and friends, by providing support and motivation to an individual embarking on a career as an entrepreneur, positively contribute to the increasing numbers of entrepreneurs. This influence is especially true in Eastern cultures, where people are greatly affected by the views and opinions of others. The findings also reveal that in Vietnamese culture, social pressure on individuals to perform or not perform a certain behavior positively impacts their attitude to entrepreneurship. The results are consistent with Doanh (2019), who highlighted the important role of social norms in forming attitudes and cognition. This study confirms the importance of normative beliefs in predicting attitudes in a collectivist culture.

The literature indicates that creativity plays an important role in entrepreneurial processes (Ward, 2004). However, the results show that creativity has no significant direct impact on entrepreneurial intention. This finding is not consistent with the research of Hamidi et al. (2008), but it is in line with the research of Minano and Campo (2017), Schmidt et al. (2012)m Rui et al. (2018), and Zampetakis and Moustakis (2006). The differences in results may be explained by mediator effects. The results of this study support the suggestions by Miranda et al. (2017) and Zampetakis and Moustakis (2006) that individuals with a strong anchor in creativity are motivated and have a favorable attitude to creating something new or becoming self-employed. This research also found a positive mediating effect of attitude on the association between creativity and entrepreneurial intention. A high level of creativity creates a more positive attitude in individuals' minds to entrepreneurship, and through it, leads to a firm intention to initiate entrepreneurial activities. Furthermore, creativity impacts students' confidence to start a new business. Although creativity alone will not stimulate favorable intentions to start a new venture, individual creativity helps individuals to believe in their abilities and gain confidence that they could undertake the risky task of venturing into a new business.

In line with Biraglia and Kadile (2016) and Shahab et al. (2018), positively perceived behaviour control mediates the relationship between creativity and intention. To stimulate a favorable intention to make a career in entrepreneurship, we need to increase students' confidence to start a new business. The results show that self-belief in creativity has an impact 
on the individual perception of the social environment (family, friends, and co-workers), and through social norms decisively influences the person's entrepreneurial intention. The findings also support the proposition that the decision to engage in entrepreneurial ventures lies in individual perceptions rather than in "objective reality" (Krueger et al., 2000; Zampetakis and Moustakis, 2006).

\section{Conclusion}

The purpose of the study was to utilize the TPB model to explore the impact of creativity on entrepreneurial intention in undergraduate students. The results support previous findings from the TPB model in entrepreneurship research. In addition, SEM showed that creativity has no significant direct effect on entrepreneurial intention; rather, it has an indirect effect on entrepreneurial intention through three determinants (attitude, subjective norms, and behavioral control). In the context of a collectivist culture, subjective norms positively link to attitude and entrepreneurial intention. The research has limitations that should be considered. First, there might be other variables controlling and influencing the relationship between creativity and entrepreneurial intention. Therefore, it would be interesting for future research to establish whether other variables influence this relationship, by testing other mediator and moderator effects. Second, the cross-sectional study design did not allow us to analyze the reverse causality of the impact of creativity on intention and behavior. A longitudinal study would provide an understanding of the causality of the relationships between the variables. Future research may also consider entrepreneurial actions and the role of creativity in the transition from entrepreneurial intention to entrepreneurial actions. A longitudinal survey design would be best to examine entrepreneurial actions. Finally, as this study was conducted in an Asia collectivist developing country, it would be interesting to compare our findings with other cultural contexts.

\section{References}

Ajzen, I. (1991). The theory of planned behaviour. Organizational Behaviour and Human Decision Processes, 50(2), 1-63. https://doi.org/10.1080/08870446.2011.613995

Baughn, C. C., Cao, J.S.R., LE, L.T.M, Lim, V. A. \& Neupert, K.E (2006). Normative, Social and Cognitive predictors of entrepreneurial interest in China, Vietnam and the Philippines. Journal of Development Entrepreneurship, 11(1), 57-77. https://doi.org/10.1142/S108494670600026X 
Begley, T.M. and Tan, W. (2001). The socio-cultural environment for entrepreneurship: A comparison between East Asian and Anglo-Saxon countries. Journal of International Business Studies, 32(3), 537-553. https://doi.org/10.1057/palgrave.jibs.8490983

Biraglia, A. and Kadile, V. (2016). The Role of Entrepreneurial Passion and Creativity in Developing Entrepreneurial Intentions: Insights from American Homebrewers. Journal of Small Business Management, 55(1), 170-188. https://doi.org/10.1111/jsbm.12242

Bird, B. J. (1988). Implementing entrepreneurial ideas: The case for intention. Academy of Management Review, 13(3), 442-453. https://doi.org/10.2307/258091

Bruton, G., Ahlstrom, D. and Obloj, K. (2008). Entrepreneurship in Emerging Economies: Where Are We Today and Where Should the Research Go in the Future.

Entrepreneurship: Theory and Practice, 32(1), 1-14. https://doi.org/10.1111/j.15406520.2007.00213.x

Duong, C. D. and Bernat, T., (2019). Entrepreneurial self-efficacy and intention among Vietnamese students: a meta-analytic path analysis based on the theory of planned behavior. Procedia Computer Science, 159, 2447-2460. https://doi.org/10.1016/j.procs.2019.09.420

Feldman, D. \& Bolino, Mark. (2000). Career Patterns of the Self-Employed: Career Motivations and Career Outcomes. Journal of Small Business Management, 38(3), 5367. https://doi.org/10.1.1.467.5387

Fillis, I., and Rentschler, R., (2010). The Role of creativity in Entrepreneurship. Journal of Enterprising Culture, 18(1), 49-81, https://doi.org/10.1142/S0218495810000501

Hair, J. F. Jr, Black, W. C., Babin, B. J. and Anderson, R. E. (2010). Multivariate Data Analysis, 7th ed. New York: Prentice-Hall.

Hamidi, D. Y., Wennberg, K. and Berglund, H. (2008). Creativity in entrepreneurship education. Journal of Small Business and Enterprise Development, 15(2), 304-320. https://doi.org/10.1108/14626000810871691

Hofstede, G. (2001). Culture's Consequences (2nd Edition): Comparing Values, Behaviours, Institutions, and Organizations Across Nations. London: Sage Publications.

Hu, L., Bentler, P.M. (1999). Cutoff Criteria for Fit Indexes in Covariance Structure Analysis: Conventional Criteria Versus New Alternatives. SEM. 6(1), 1-55. https://doi.org/10.1080/10705519909540118

Krueger, N.F., Reilly, M. and Carsrud A. (2000). Competing models of entrepreneurial intentions. Journal of Business Venturing, 15(5/6), 411-432.

https://doi.org/10.1016/S0883-9026(98)00033-0 
Laguíaa, A., Morianoa, J.A., and Gorgievskib, M.J. (2019). A psychosocial study of selfperceived creativity and entrepreneurial intentions in a sample of university students. Thinking Skills and Creativity, 31(1), 44-57. https://doi.org/10.1016/j.tsc.2018.11.004

Linán, F., \& Chen, Y. W. (2009). Development and cross-cultural application of a specific instrument to measure entrepreneurial intentions. Entrepreneurship Theory and Practice, 33(3), 593-617. https://doi.org/10.1111/j.1540-6520.2009.00318.x

Mario R.B., Antonia, M.G. and Domingo, G.P.L. (2018). The effects of personal abilities and self-efficacy on entrepreneurial intentions. International Entrepreneurship and Management Journal. 14(1), 1025-1052. https://doi.org/10.1007/s11365-017-0469-0

Minano, M.C., Campo, C.D. (2017). The role of creativity in entrepreneurship: An empirical study on Business undergraduates. Education + Training, 59(7/8), 672-688. https://doi.org/10.1108/ET-08-2016-0132

Miranda, F.J., Mera, A.C., and Rubio, S. (2017), Academic entrepreneurship in Spanish universities: An analysis of the determinants of entrepreneurial intention. European Research on Management and Business Economics, 23(2), 113-122. https://doi.org/10.1016/j.iedeen.2017.01.001

Nguyen, P. M., Dinh, V.T., Luu, T.M.N. \& Choo Y., (2020). Sociological and theory of planned behaviour approach to understanding entrepreneurship: Comparison of Vietnam and South Korea. Cogent Business \& Management, 7(1), 1-21. https://doi.org/10.1080/23311975.2020.1815288

Pereira, B., Figlioli, A., de Oliveira, D., and\& da Silva, E. (2018). Expansion and Evolution of Incubation Programs and Entrepreneurship Development In Incubators In The State of Goiás, Brazil. International Journal of Innovation, 6(1), 68-84. https://doi.org/10.5585/iji.v6i1.62

Preacher, K. J., and A. F. Hayes (2004). SPSS and SAS Procedures for Estimating Indirect Effects in Simple Mediation Models. Behaviour Research Methods, Instruments, \& Computers 36(4), 717-731. https://doi.org/10.3758/BF03206553

Rui, H., Li, W., Wei, Z. and Peng, B. (2018). Creativity, Proactive Personality, and Entrepreneurial Intention: The Role of Entrepreneurial Alertness. Frontiers in Psychology, 9(951), 1-10. https://doi.org/10.3389/fpsyg.2018.00951

Schmidt, J.J., Soper, J.C. and Facca, T.M. (2012). Creativity in the entrepreneurship classroom. Journal of Entrepreneurship Education, 15(3): 123-131.

Schmitz, A. \& Urbano, D. \& Dandolini, G. \& Souza, J. \& Guerrero, M. (2017). Innovation and Entrepreneurship in the Academic Setting: A Systematic Literature Review. International Entrepreneurship and Management Journal. 13(2), 369-395. https://doi.org10.1007/s11365-016-0401-z

Shahab, Y., Chengang, Y., Arbizu, A.D, and Haider, M.H. (2018). Entrepreneurial selfefficacy and intention: do entrepreneurial creativity and education matter?. 
International Journal of Entrepreneurial Behaviour \& Research, 25(2), 259-280. https://doi.org/10.1108/IJEBR-12-2017-0522

Smith, R.M., Sardeshmukh, S.R. and Combs, G.M. (2016), Understanding gender, creativity, and entrepreneurial intentions. Education + Training, 58(3), 263-282.

https://doi.org/10.1108/ET-06-2015-0044

Tsai, K.H. \& Chang, H.C. \& Peng, C.Y. (2016). Extending the link between entrepreneurial self-efficacy and intention: a moderated mediation model. International Entrepreneurship and Management Journal. 12(2), 445-463. https://doi.org/10.1007/s11365-014-0351-2

Ward, T. B. (2004). Cognition, creativity and entrepreneurship. Journal of Business Venturing, 19(2): 173-188. https://doi.org/10.1016/S0883-9026(03)00005-3

Yousaf, U., Shamim, A., Siddiqui, H., \& Raina, M. (2015). Studying the influence of entrepreneurial attributes, subjective norms and perceived desirability on entrepreneurial intentions. Journal of Entrepreneurship in Emerging Economies, 7(1), 23-34. https://doi.org/10.1108/JEEE-03-2014-0005

Zampetakis, L.A. and Moustakis, V. (2006), Linking creativity with entrepreneurial intentions: a structural approach. Entrepreneurship Management, 2(3), 413-428. https://doi.org/10.1007/s11365-006-0006-z. 